\title{
PARTICIPATION OF NON-GOVERNMENTAL NON-PROFIT ORGANIZATIONS IN THE ASSESSMENT OF THE REGULATORY IMPACT OF DRAFT REGULATORY LEGAL ACTS ON BUSINESS ACTIVITIES IN REPUBLIC OF UZBEKISTAN
}

\author{
Bobur Muqumov \\ Teacher at Intellectual property department, Tashkent state university of law, Tashkent, Uzbekistan. \\ E-mail: bmuqumov@gmail.com
}

\begin{abstract}
:
This article analyzes the activities of the chamber of Commerce and industry of the Republic of Uzbekistan in the implementation of public expertise of draft regulatory legal acts, the experience of foreign countries in the application of the Institute of regulatory impact assessment. Based on the analysis, relevant proposals were made for the effective application of the Institute for regulatory impact assessment in the Republic of Uzbekistan.

Keywords: public control, public expertise, Chamber of commerce and industry, regulatory impact assessment (RIA).

Article Received: 18 October 2020, Revised: 3 November 2020, Accepted: 24 December 2020
\end{abstract}

\section{Introduction}

Today, large-scale work is being carried out in Uzbekistan to improve the quality of rulemaking activities, the introduction of new innovative methods of "smart regulation" that allow making deeply calculated and balanced government decisions, with broad public involvement in the rule-making process.

Regulations are indispensable for the proper functioning of economies and societies. They create the "rules of the game" for citizens, business, government and civil society. They underpin markets, protect the rights and safety of citizens and ensure the delivery of public goods and services. The objective of regulatory policy is to ensure that the regulatory "lever" works effectively, so that regulations and regulatory frameworks work in the public interest.

The quality of both the regulatory environment and regulatory outcomes is strongly dependent on the quality of processes for designing regulations. When developing interventions, whether policies, laws, regulations or other types of "rule", governments do not always fully consider their likely effects. In addition, government intervention has costs, which might, in some cases, outweigh the anticipated benefits. As a result, there are many instances of unintended consequences and, ultimately, negative impacts for citizens, businesses and society as a whole that essentially result from badly designed interventions.

As you know, the President, by the Decree of August 8, 2018, approved the Concept for improving the rule-making activity. The concept marked the beginning of a new stage in the rule-making activity in the country. [1]

In accordance with the Concept, the rulemaking process is filled with completely new content. The system of ordering public relations is completely eradicated, which has not justified itself in practice. [1]

The role of the public in the discussion of draft laws

An analysis of law enforcement practice showed that some decisions of state bodies are made without a deep study of their possible consequences and the resources of state bodies and economic entities necessary for their implementation, and control over their implementation did not always allow timely identification and correction of ineffective measures. As a result, the set goals are not always 
achieved, which makes it necessary to reconsider the decision.[2]

Due to the intensively changing modern realities, the newly adopted and existing decisions sometimes come into conflict with each other, which adversely affects the implementation of entrepreneurial activities and the investment attractiveness of the republic.

In this regard, in recent years, great attention has been paid to the implementation of public control over the rule-making process by civil society institutions.

According to the Law of the Republic of Uzbekistan dated April 12, 2018, No. 3PУ-474 "On public control", one of the forms of public control is "public examination", which is the study and assessment of draft regulatory legal acts and other decisions of state bodies on the subject of their compliance with the rights and legitimate interests of citizens, legal entities, the interests of society. [3]

Public expertise can be carried out by non-governmental non-profit organizations, citizens' self-government bodies and the media in cases stipulated by law. [3]

It should be noted that the subjects of public expertise are widely involved in the rulemaking process. Public discussions are held on normative legal acts of great social importance.

Civil institutions took an active part in public examinations of draft laws "On public control in the Republic of Uzbekistan", "On environmental control", "On social partnership", "On the openness of the activities of public authorities and management" and many others. [4]

Examination of draft regulatory legal acts allows ensuring the protection of business entities from artificially created barriers in the course of entrepreneurial activities, and also strengthens their legal guarantees.

Role of the Chamber of Commerce and Industry of the Republic of Uzbekistan in Regulatory Impact Assessment
The Chamber of Commerce and Industry of the Republic of Uzbekistan is a non-state nonprofit organization uniting business entities.

According to the Law of the Republic of Uzbekistan dated July 9, 2018, No. 3PУ-483 "On the Chamber of Commerce and Industry of the Republic of Uzbekistan", the Chamber exercises public control over the implementation of regulatory legal acts in the field of entrepreneurial activity by carrying out, with the involvement of business entities, a public examination of regulatory legal acts and their projects to assess their impact on entrepreneurial activity. [5]

Fulfilling the assigned functions, only in 2020 the Chamber conducted a public examination with the participation of business entities of $\mathbf{8 9 0}$ draft regulatory legal acts, of which 578 projects identified provisions that would negatively affect business development. [6]

Despite the fact that the drafts of regulatory legal acts developed during this period were mainly aimed at ensuring greater freedom of business entities, simplifying various types of procedures for engaging in entrepreneurial activity, $60 \%$ of them directly or indirectly affected the interests of business entities and had a negative impact on entrepreneurial activity.

It should be noted that public examination of draft regulatory legal acts is primarily aimed at reducing the costs of stakeholders (business entities), ensuring budget savings, reducing the risk of corruption, as well as increasing the confidence of citizens and businesses in those taken from outside. state decisions.

When conducting a public examination of draft regulatory legal acts, the positive experience of foreign countries with developed economies in the field of regulated relations is studied.

The final result of public expertise is an increase in the efficiency of government regulation in a particular industry. 
In case of disagreement with the content of the draft normative legal act as a whole or in any part of it, the Chamber submits an appropriate opinion to the body adopting the normative legal act. [5]

It should be noted that the draft regulatory legal acts on issues that directly or indirectly affect the implementation of entrepreneurial activity are subject to mandatory approval by the Chamber.[5]

This provision is reflected in such regulatory legal acts as the Law of the Republic of Uzbekistan "On the Chamber of Commerce and Industry of the Republic of Uzbekistan", Resolution of the Cabinet of Ministers dated March 22, 2019 No. 242 "On approval of the regulations of the Cabinet of Ministers of the Republic of Uzbekistan" and an order of the Minister of Justice of the Republic of Uzbekistan dated February 28, 2014 No. 2565 "On the approval of the rules for the preparation and adoption of departmental regulations".

Recommendations and written requests of the Chamber on the need to make changes and additions, as well as to invalidate the regulatory legal acts that impede or restrict the development of entrepreneurial activity, are subject to mandatory consideration within the time limits established by law, followed by sending to the Chamber reasoned conclusions on the results of their consideration. [5]

Experience of foreign countries in assessing the regulatory impact of draft laws

Today, in the republic and in the world as a whole, there is no unified generally recognized universal methodology and practice that would be used to assess the regulatory impact.

The earliest initiatives in the area of regulatory impact assessment of draft regulations were taken in 1966 in Denmark. In the 1970s, this mechanism began to be introduced in the USA, Finland and Canada. Australia, Great Britain, Holland and Germany joined this process in the mid-1980s. Since the 1990s, the number of states that have implemented an RIA system or its individual elements has increased dramatically. The most widespread regulatory impact assessment was gained in the 2000s, when in most developed countries the question arose of optimizing state regulation in order to reduce unreasonable administrative barriers that impede entrepreneurial activity. In October 2010, the European Union adopted the "Smart Regulation in the EU" doctrine, which laid the foundation for the further development of RIA procedures and the improvement of public consultation mechanisms for the adoption of draft regulatory legal acts and the subsequent assessment of their effectiveness. [7]

In some countries, the RIA procedure is sometimes legislated at the constitutional level (for example, in Switzerland and France). The methodology for conducting RIA is specific for each country and depends on the focus on which such analysis is directed. Therefore, the guidelines for regulatory impact assessment adopted in different countries also differ.

There are three groups of countries in which:

- the RIA procedure takes place only in case of adoption of a normative act providing for budgetary expenditures - USA, Canada;

- the RIA procedure takes place upon the adoption of any regulatory act - the Netherlands, Great Britain;

- the RIA procedure is not introduced, but general principles are declared under which regulatory measures are introduced only when their expediency is proven - South Korea, Czech Republic. [8]

\section{Experience of the USA}

In the United States, RIA has been introduced since the 1980s. This was a response to the demands of entrepreneurs to take into account the benefits and costs of measures taken by the state to regulate the economy. At first, assessment expanded to government programs. The scope of acts and areas of regulation required for 
performance analysis has been constantly expanding. By the end of the first decade of the XXI century. regulation covered $80 \%$ of social enterprises and almost $20 \%$ of business. Thus, the United States is distinguished by the thoroughness of the validity of regulatory measures, that is, only measures initiated by the business itself are allowed. The procedure for selecting acts for the passage of RIA has been thought out, limiting their list to only large-scale ones, requiring costs over \$ 100 million. A centralized information and regulation service has been created under the Department of Administrative and Budgetary Management, which includes 50 specialists of various specialties. [11]

\section{Experience of the UK}

The beginning of the procedures for conducting RIA in the UK dates back to 1985 and is associated with the adoption of the so-called "Deregulation Initiative". The sphere of regulation has developed and expanded, since 1998 one can speak of its comprehensive nature. Its center Regulatory Impact Unit - reports directly to the Cabinet of Ministers. At the same time, each ministry has branches of the RIA. A feature of the English approach is considered to be an emphasis on costs, rather than overall assessment. There is a constant exchange of experience in the country, for which the "Better Regulation" task force has been established, and the National Audit Office conducts an annual review of progress.

\section{Experience of the German}

The German Regulatory Impact Assessment is highly developed. Each ministry is obliged to implement RIA already at the stage of drafting the law. The Ministry of Internal Affairs is responsible for the quality of assessments, but in cooperation with the ministries of finance and economy, RIA is used both at the state level and in the provinces. A distinctive feature of Germany is the depth of cost accounting methodology. Here, both direct and indirect costs are taken into account, the latter assess changes in taxes, banking system [12], employment, ecology, etc. Depending on the scale of the assessed act, the time for conducting an RIA can take from four weeks to a year [14].

Despite the different procedures for implementing RIA, such an analysis is aimed at obtaining answers to the following questions:

- is the state intervention justified, is it possible to resolve the existing situation by other, market methods;

- how effective is the decision taken, whether the benefits that will be received by all parties from its adoption exceed the costs incurred;

- whether the solution is optimal whether all alternative solutions have been evaluated;

- Do the decisions made affect the interests of business entities, do they restrict competition;

- whether it is necessary to maintain the current requirement / regulation in the future. [9]

The principles are intended to be relevant and useful to all member governments. They thus offer general guidance rather than providing detailed prescription. Nevertheless, in seeking to invoke "best practice" the principles are intentionally ambitious. Few if any countries could be expected at this point to meet them all.

However, they are also grounded in the actual experience of different countries, so should not be seen as unattainable or merely aspirational. At the same time, the OECD understands that there are limits to the absorptive capacity of policy makers to implement all requirements for RIA implementation [13]. Governments should use an approach that will not just widen the gap between what exists "on paper" and the actual implementation. It is important to make sure that policies are implemented in practices rather to update them to "tick all the boxes" in the Principles. [10]

If used systematically and as a government-wide approach, regulatory impact assessment (RIA) provide a critical tool to ensure greater quality of government intervention. In addition, the documentation and publication of the 
evidence and analysis to design interventions provides the opportunity to enhance accountability and transparency in the policy-making and decision-making processes. Regulatory impact assessment provides crucial information to decision makers on whether and how to regulate to achieve public policy goals. It is challenging to develop "correct" policy responses which also maximize societal well-being. It is the role of RIA to help assist with this, by critically examining the impacts and consequences of a range of alternative options. Improving the evidence base for regulation through RIA is one of the most important regulatory tools available to governments. [10]

\section{Conclusion}

Based on the above, as well as in order to effectively use the institution of regulatory impact assessment in the Republic of Uzbekistan, it is necessary:

$\checkmark$ Develop a single document regulating the issues of conducting a regulatory impact assessment (RIA);

The functions of conducting RIA should be divided between the relevant state bodies and other organizations by field of activity, while defining a specific list of these entities;

$\checkmark \quad$ Create a specially authorized body to coordinate the activities of state bodies and other organizations for conducting RIA, and control the quality of the assessment;

$\checkmark \quad$ Develop a unified approach to the implementation of the RIA system, covering the entire legislative process, while it is necessary to provide that any draft regulatory legal act should be the subject of RIA.

References

[1] http://parliament.gov.uz/ru/laws/norm/291 94/

[2] http://infocom.uz/2016/03/31/znachimostvnedreniya-sovaz-na-predprinimatelskuyudeyatelnost/.://parliament.gov.uz/ru/laws/n orm/29194/
[3] The Law of the Republic of Uzbekistan dated April 12, 2018, No. 3РУ-474 “On public control".

https://mfa.uz/ru/press/news/2020/01/2231 2/

[4] Law of the Republic of Uzbekistan dated July 9, 2018, No. 3РУ-483 "On the Chamber of Commerce and Industry of the Republic of Uzbekistan" http://www.chamber.uz/ru/news/5576/

[5] http://bujet.ru/article/251054.php?print=Y

[6] Рочева Е.А. «Оценка регулирующего воздействия как перспективный этап нормотворческой деятельности» Научно-практический центр проблем укрепления законности и правопорядка Генеральной прокуратуры Республики Беларусь (www.elib.bsu.by) http://infocom.uz/2016/03/31/znachimostvnedreniya-sovazna predprinimatelskuyu -deyatelnost/

[7] OECD (2020), Regulatory Impact Assessment, OECD Best Practice Principles for Regulatory Policy, OECD Publishing, Paris, https://doi.org/10.1787/7a9638cb-en.

[8] http://www.goskontrol-rspp.ru/analyticalmaterials/20-opyt-stran-organizaciijekonomicheskogosotrudnichestva-irazvitija-po-ocenke-regulirujuwegovozdejstvija.html.

[9] Khujayev, Shokhjakhon Akmaljon. "JUDGMENTS UNDER THE LAW OF THE REPUBLIC OF UZBEKISTAN «ON BANKS AND BANK ACTIVITY» IN THE NEW EDITION." International Journal of Legal Studies (IJOLS) 4.2 (2018): 295-301.

[10] Юлдашов, Абдумумин. "ИНТЕЛЛЕКТУАЛ МУЛК БЎЙИЧА МИЛЛИЙ СТРАТЕГИЯЛАРНИНГ АХАМИЯТИ ВА БУТУНЖАХОН ИНТЕЛЛЕКТУАЛ МУЛК ТАШКИЛОТИНИНГ БУ БОРАДА 
ТУТГАН ЎРНИ." ЮРИСТ

АХБОРОТНОМАСИ 1.2 (2020): 53-59.

[11] Mokhinur, Bakhramova. "A THOROUGH

REVIEW OF THE COMMON LAW

CONCEPT OF" ARBITRARY

TERMINATION" AND" UNFAIR

DISMISSAL"(including DIFC\&ADGM."

Review of law sciences NOVEMBER

(2020). 